Published by LPMP Imperium

Journal homepage: https:/ / ejournal.imperiuminstitute.org/ index.php/JMSAB

\section{Dampak investasi sektor pertambangan hulu migas terhadap nilai tambah bruto penyerapan tenaga kerja dan import content di Indonesia}

\author{
Nazorry Effendy \\ STIE Pengembangan Bisnis \& Manajemen, Jakarta, Indonesia
}

\section{JMSAB}

\section{5}

Paper type

Point view

\begin{abstract}
This paper aims to provide an important point of view on the impact of investment in the upstream oil and gas mining sector on gross added value (business surplus, wages, depreciation, and indirect taxes), transportation of labor, and imports. Research data were collected through external sources and synthesized with critical analysis to explain the linkages of the Indonesian mining investment sector. In general, the results of the study show that investment in the upstream oil and gas mining sector has a positive impact on the gross added value of its components (business surplus, wages, and revenues, depreciation, indirect taxes), employment search, and content import. Implications and suggestions are explained in this paper.
\end{abstract}

\begin{abstract}
Abstrak
Artikel ini bertujuan untuk memberikan catatan penting (point view) mengenai dampak investasi sektor Penambangan hulu migas terhadap nilai tambah bruto (surplus usaha, upah, penyusutan, dan pajak tak langsung), pengangkutan tenaga kerja, dan impor. Data penelitian dikumpulkan melalui sumber eksternal dan disintesa dengan analisis kritis untuk menjelaskan keterkaitan sektor investasi pertambangan Indonesia. Secara umum, hasil penelitian menunjukkan bahwa investasi sektor pertambangan hulu migas berdampak positif terhadap nilai tambah bruto dari komponennya (surplus usaha, upah dan penerimaan, penyusutan, pajak tak langsung), pencarian tenaga kerja, dan impor konten. Implikasi dan saran penelitian saran dalam artikel.
\end{abstract}

*Email korespondensi: nazorry@yahoo.co.id

Pedoman Sitasi: Effendy, N (2019). Dampak investasi sektor pertambangan hulu migas terhadap nilai tambah bruto penyerapan tenaga kerja dan import content di Indonesia. Jurnal Manajemen Strategi dan Aplikasi Bisnis, 2(2) , 145-154
Received: 01 Aug 2019

Revised: 24 Aug 2019

Accepted: 26 Aug 2019

Online: 31 Aug 2019

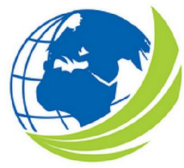

Jurnal Manajemen Strategi dan Aplikasi Bisnis, Vol 2, No. 2 , Desember 2018, pp. 145-154

eISSN 2655-237X 


\section{PENDAHULUAN}

Masalah-masalah yang terkait dengan energy telah menjadi isu yang mendapatkan perhatian hampir di semua negara di dunia. Di banyak negara berkembang seperti Indonesia, konsumsi energi telah meningkat pesat, mengakibatkan masalah terkait energi seperti kekurangan daya dan polusi lingkungan. Masalah-masalah ini sangat mengancam pembangunan berkelanjutan dan menimbulkan keprihatinan besar di semua tingkatan masyarakat, dari masyarakat umum hingga pemerintah nasional hingga lembaga internasional. Karena beratnya masalah terkait energi, pemerintah banyak negara berkembang telah mulai memperkenalkan kebijakan dan peraturan energi untuk menghadapi masalah ini. Niat dengan sebagian besar kebijakan terkait energi adalah untuk mempengaruhi proses sedemikian rupa yang mengarah pada penggunaan sumber daya yang lebih efisien atau lebih hati-hati dan perilaku yang lebih berkelanjutan secara lingkungan.

Indonesia merupakan salah satu negara berkembang yang memiliki permasalahan terkait dengan energy. Kenaikan harga minyak dunia memiliki dampak langsung pada pengeluaran negara yang kemudian menyebabkan pemerintah mulai mengalihkan subsidi bahan bakar minyak (BBM) ke bentuk program lain yang dianggap lebih efektif. Tingginya tingkat konsumsi yang tidak dibarengi dengan produksi menyebabkan Indonesia bukan lagi negara pengeksport minyak, melainkan negara yang mengimpor minyak dari luar negeri. Berdasarkan data dari Kementerian Energi dan Sumber Daya Mineral (ESDM) tahun 2017, kebutuhan BBM dalam negeri Indonesia adalah sebesar 1,3 juta barel per hari (bopd), sedangkan produksi minyak mentah hanya mencapai 525 ribu bopd atau 59\% dari total kebutuhan BBM. Sedangkan sisanya sebesar $41 \%$ minyak mentah di impor dari luar negeri. Kondisi ini jelas memperlihatkan bahwa Indonesia memiliki permasalahan serius terkait dengan energy, dan kebijakan di bidang energi menjadi penting dalam upaya meningkatkan sustainabilitas pembangunan Indonesia.

Masih tingginya kebergantungan Indonesia pada sumber energi migas, khususnya minyak bumi, sementara sumber energi non migas belum banyak dikembangkan. Makin terbatasnya cadangan minyak bumi dalam negeri yang dapat dieksploitasi sementara kebutuhan BBM baik untuk konsumsi masyarakat maupun konsumsi industri terus meningkat. Walaupun produksi gas alam mengalami peningkatan setiap tahunnya tetapi produksi minyak bumi terus menurun. Kebijakan pemerintah untuk lebih mendahulukan ekspor sebagian hasil produksi migasnya ke beberapa negara, seperti Jepang, Korea Selatan dan China, sementara kebutuhan konsumsi dalam negeri yang kurang justru dipenuhi dari impor.

Artikel ini bertujuan untuk meninjau efek dari kebijakan terkait energy, terutama dari sisi kebijakan investasi sektor hulu migas. Artikel ini akan memberikan poin-poin penting dari kebijakan investasi sektor hulu migas dan efeknya pada nilai tambah bruto (surplus usaha, upah, penyusutan, dan pajak tak langsung), pengangkutan tenaga kerja, dan impor. Hasil penelitian ini kelak dapat memberikan informasi kepada pemerintah dan para investor yang ingin bergerak di sektor tambang migas tentang nilai tambah bruto yang dihasilkan, bagaimana distribusi dari nilai tambah bruto tersebut, berapa banyak investasi itu menyerap tenaga kerja, dan berapa import content-nya.

\section{METODE}

Penelitian ini menggunakan pendekatan studi pustaka dan pengumpulan data sekunder dari berbagai sumber untuk membuat kesimpulan penelitian. Berbagai sumber laporan, berita, dan data mengenai kebijakan investasi hulu migas, dan nilai tambah bruto (surplus usaha, upah, penyusutan, dan pajak tak langsung), pengangkutan tenaga kerja, dan impor dikumpulkan, kemudian disintesa dan dianalisis sehingga dapat diperoleh poin-poin penting mengenai informasi yang disajikan. 


\section{DATA DAN PEMBAHASAN}

Konsumsi dan produksi minyak Indonesia

Sejak tahun 2000an, Indonesia sudah mengalami tren penurunan produksi minyak mentah secara konstran penurunan yang dipertahankan karena tidak adanya peningkatan eksplorasi dan investasi yang signifikan sektor ini. Konsumsi minyak yang cenderung meningkat tidak diimbangi dengan kenaikan produksi menyebabkan Indonesia telah mengalami defisit minyak sejak tahun 2003, dan terus berlanjut sampai dengan sekarang. Berdasarkan data BP, produksi minyak Indonesia pada 2003 sebesar 1,18 juta barel per hari sementara konsumsi mencapai 1,23 juta barel, sehingga terjadi defisit yang cukup besar 54 ribu barel per hari. Tahun-tahun berikutnya, produksi minyak indonesia hanya sebesar 949 ribu barel per hari (di tahun 2017) sementara konsumsi malah meningkat menjadi 1,65 juta barel. Kondisi ini menyebabkan defisit yang cukup besar yaitu 702 barel per hari untuk memenuhi kebutuhan minyak dalam negeri. Di tahun 2018, berdasarkan data dari BP Global Company (2019), konsumsi minyak Indonesia sudah hampir mencapai 1.8 juta barel per hari, sedangkan produksi hanya sebesar 800 ribu barel.

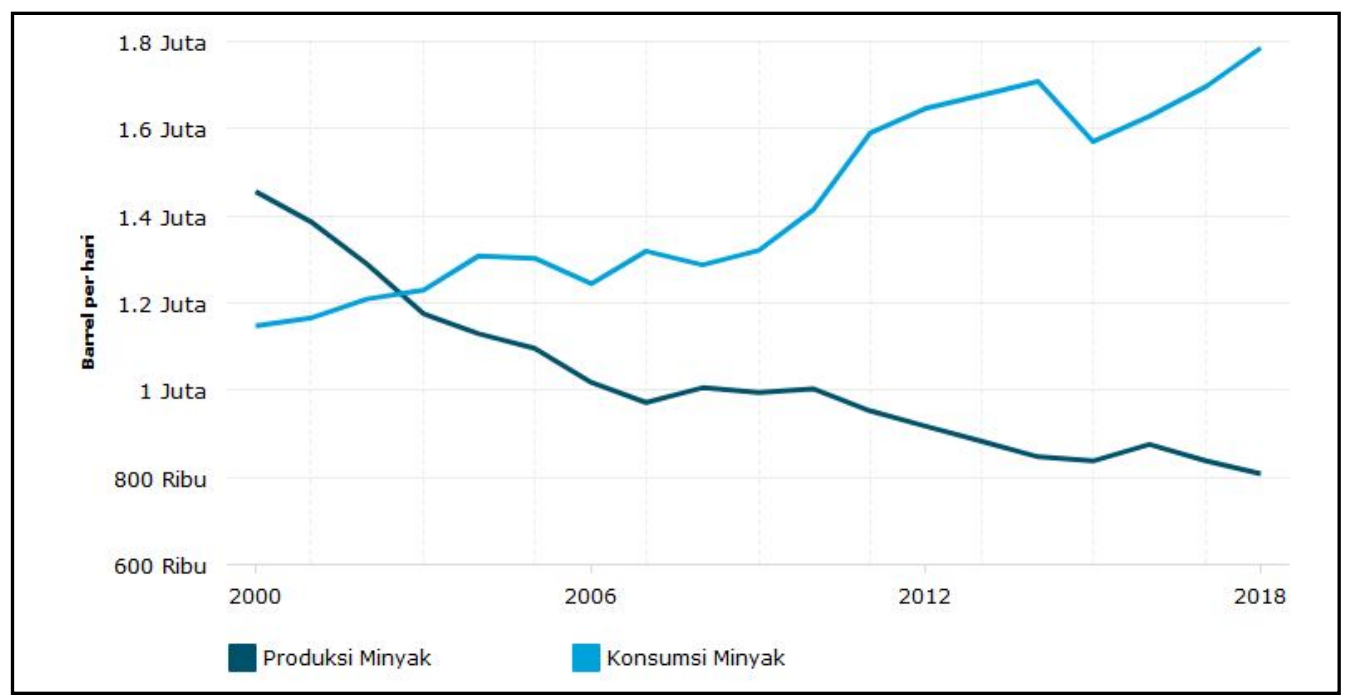

Sumber: BP Global company (2019)

Gambar 1. Perbandingan Produksi dan Konsumsi Minyak Indonesia tahun 2000 - 2018

Neraca perdagangan minyak Indonesia di tahun 2018 mencapai 13,79\% yaitu sebesar 977 ribu barel per hari dibandingkan tahun sebelumny. Semakin besarnya defisit minyak disebabkan kenaikan yang signifikan konsumsi sebesar 5,24\% menjadi 1,79 juta barel per hari dan diikuti penurunan produksi 3,52\% menjadi 808 ribu barel per hari. Kondisi di atas memperlihatkan bahwa sektor perminyakan Indonesia merupakan masalah serius yang perlu ditangani secara sistematis untuk mencegah defisit yang lebih besar.

Upaya pemerintah untuk pengalihan konsumsi BBM

Untuk mengurangi ketergantungan pada konsumsi minyak, beberapa kebijakan pemerintah dikeluarkan, diantaranya kebijakan konversi minyak tanah ke gas pada tahun 2007. Kebijakan yang kemudian menjadi program pemerintah ini dilaksanakan lintas kementerian dan lembaga, mulai dari kementerian Koperasi dan UKM, kementerian ESDM, Pertamina sendiri sebagai produsen, dan berbagai komponen lain yang secara masif menjalankan program percepatan konversi. Melalui pembagian tabung gas elpiji gratis sampai dengan subsidi pada 
tabung gas $3 \mathrm{~kg}$ menjadikan program ini berhasil mengurangi lebih dari separuh konsumsi minyak tanah dan memberikan penghematan subsidi lebih dari 20 Trilyun di tahun 2010.

Selanjutnya, pemerintah melalui Kementerian Riset dan Teknologi DIKTI dan Kementerian ESDM membuat serangkaian kebijakan strategis di bidang energi terbarukan. Kementerian ESDM melakukan serangkaian program seperti percepatan penambahan pembangkit tenaga listrik yang bersumber dari energi terbarukan seperti solar cell, Pembangkit Listrik Tenaga Air (PLTA). Sementara Kementerian Riset dan Teknologi DIKTI yang menaungi sektor pendidikan menjadikan isu energi baru dan terbarukan sebagai prioritas riset nasional dalam Rencana Induk Penelitian Riset Nasional Tahun 2017 - 2045.

Energi terbarukan mendapatkan perhatian yang signifikan tiga puluh tahun terakhir, dan faktanya energi terbarukan merupakan sumber energi yang tumbuh paling cepat sumber di dunia sejak akhir 2000-an (Apergis, 2012). Alasan utama untuk Peningkatan energi terbarukan terkait dengan perubahan iklim, yang sudah menjadi masalah utama di dunia saat ini. Para ilmuwan sepakat bahwa produksi bahan bakar fosil memiliki efek signifikan pada rumah kaca emisi, dan ini telah menjadi sumber fundamental global pemanasan. Dengan kata lain, bahan bakar fosil dapat mendorong perubahan iklim. Perubahan iklim menjadi ancaman bagi pertumbuhan berkelanjutan (Jebli dan Yousef, 2015), karenanya pembuat kebijakan menyiapkan berbagai investasi dalam energi terbarukan, terutama di sebagian besar negara maju dan beberapa negara berkembang (seperti Indonesia, Brasil dan Cina). Selain ditujukan untuk memperlambat perubahan iklim, upaya untuk menciptakan energy terbarukan juga terkait dengan biaya energi dengan fluktuasi yang tinggi pada harga minyak mentah dunia. Tingginya biasa volatilitas harga di minyak di pasar dunia selama dua puluh tahun terakhir menjadikan salah satu alasan penting peningkatan minat pada energy alternative (terbarukan).

Investasi Sektor Pertambangan Hulu Migas dan Dampaknya terhadap Output

Berikut ini hasil analisis tentang investasi di sektor pertambangan hulu migas selama periode 2009-2013. Tampak bahwa selama periode tersebut, investasi di sektor pertambangan hulu migas terus menurun, dari Rp. 1.423.457 juta di tahun 2009 menjadi Rp. 718.487 juta di tahun 2013. Penurunan investasi di sektor pertambangan hulu migas selama periode 2009-2013 ini disebabkan sumur-sumur lama telah banyak yang kering, sedangkan eksplorasi untuk mencari sumur-sumur baru tidak ada. Banyak sebab terjadinya hal ini antara lain adanya otonomi daerah yang bertentangan dengan peraturan pusat dan proses pengurusan ijin usaha yang lambat. Rata-rata investasi di sektor pertambangan hulu migas selama periode 2009-2013 adalah sebesar Rp. 889.755 juta. 


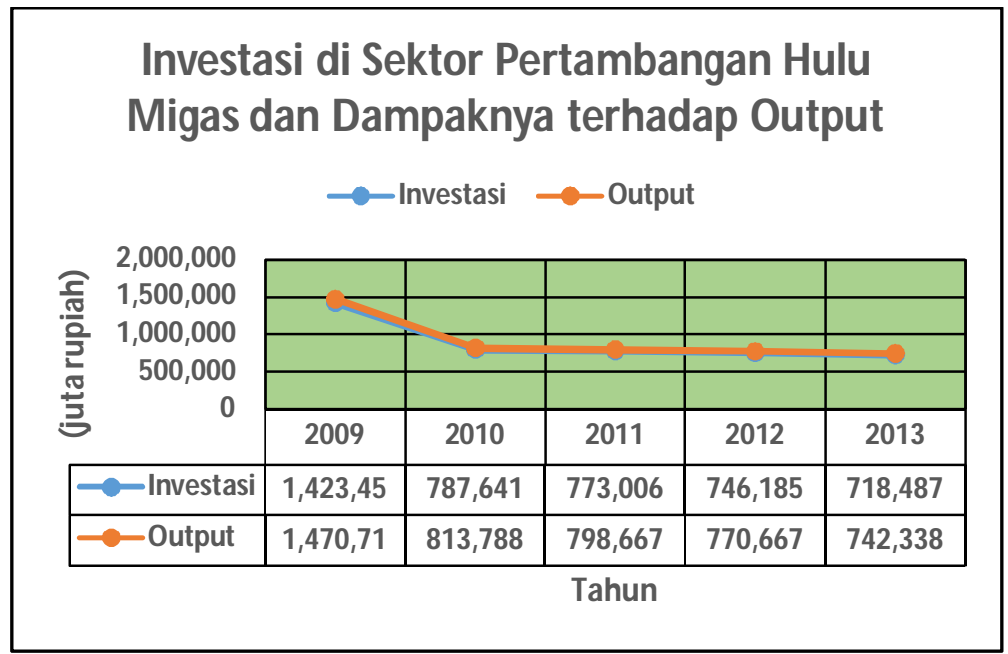

Gambar 1. Invetasi di sektor Pertambangan Hulu Migas dan dampaknya terhadap output

Dampak Investasi Sektor Pertambangan Hulu Migas terhadap Nilai Tambah Bruto

Searah dengan penurunan investasi di sektor pertambangan hulu migas, nilai tambah bruto dari sektor ini juga terus menurun selama periode 2009-2013, dari Rp. 1.388.734 juta di tahun 2009 menjadi Rp. 700.961 juta di tahun 2013. Rata-rata nilai tambah bruto di sektor pertambangan hulu migas selama periode 2009-2013 adalah sebesar Rp. 868.051 juta. Nilai tambah bruto rata-rata pertahun selama periode 2009-2013 yang diperoleh dari investasi di sektor pertambangan hulu migas adalah sebesar 97,6 persen dari investasi. Searah dengan penurunan investasi dan penurunan nilai tambah bruto di sektor pertambangan hulu migas, surplus usaha dari sektor ini juga terus menurun selama periode 2009-2013, dari Rp. 1.156.039 juta di tahun 2009 menjadi Rp. 583.508 juta di tahun 2013. Rata-rata surplus usaha di sektor pertambangan hulu migas selama periode 2009-2013 adalah sebesar Rp. 722.601 juta. Surplus usaha rata-rata pertahun selama periode 2009-2013 yang diperoleh dari investasi di sektor pertambangan hulu migas adalah sebesar 81,2 persen dari investasi.

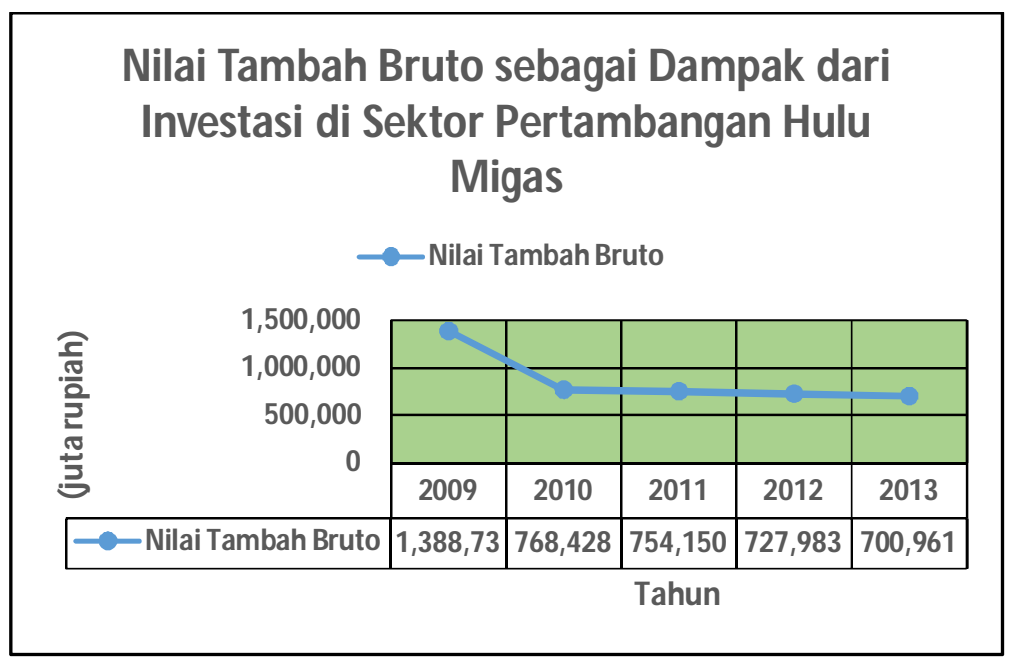

Gambar 2. Dampak Investasi di Sektor Pertambangan Hulu Migas terhadap Nilai Tambah Bruto 


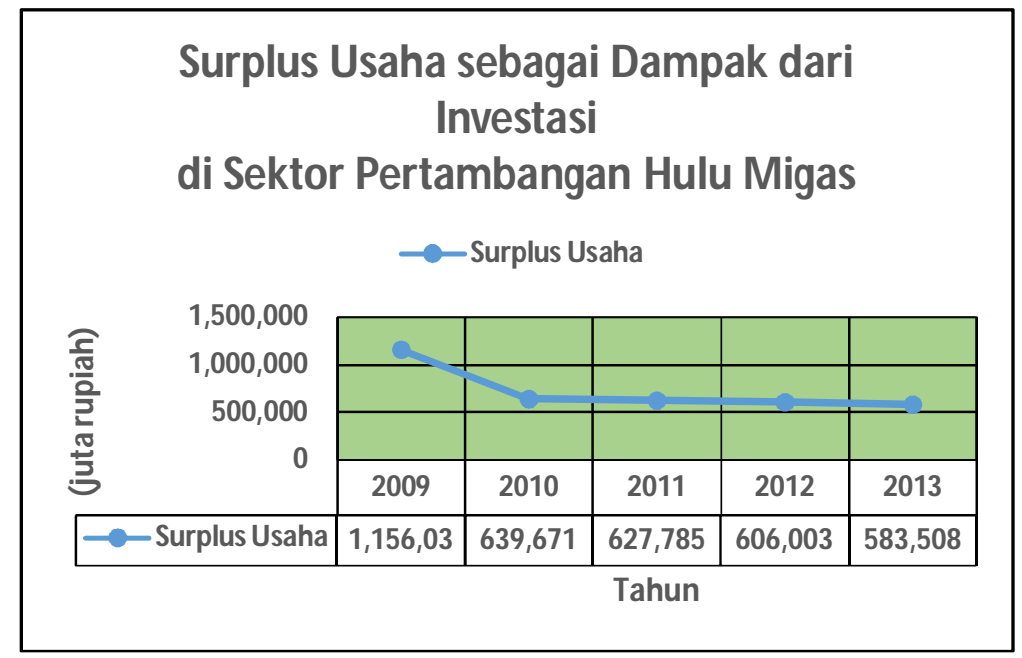

Gambar.3. Dampak Investasi di Sektor Pertambangan Hulu Migas terhadap Surplus Usaha

Searah dengan penurunan investasi dan penurunan nilai tambah bruto di sektor pertambangan hulu migas, upah dan gaji dari sektor ini juga terus menurun selama periode 2009-2013, dari Rp. 120.018 juta di tahun 2009 menjadi Rp. 60.579 juta di tahun 2013. Rata-rata upah dan gaji di sektor pertambangan hulu migas selama periode 2009-2013 adalah sebesar Rp. 75.019 juta. Upah dan gaji rata-rata pertahun selama periode 2009-2013 yang diperoleh dari investasi di sektor pertambangan hulu migas adalah sebesar 8,4 persen dari investasi.

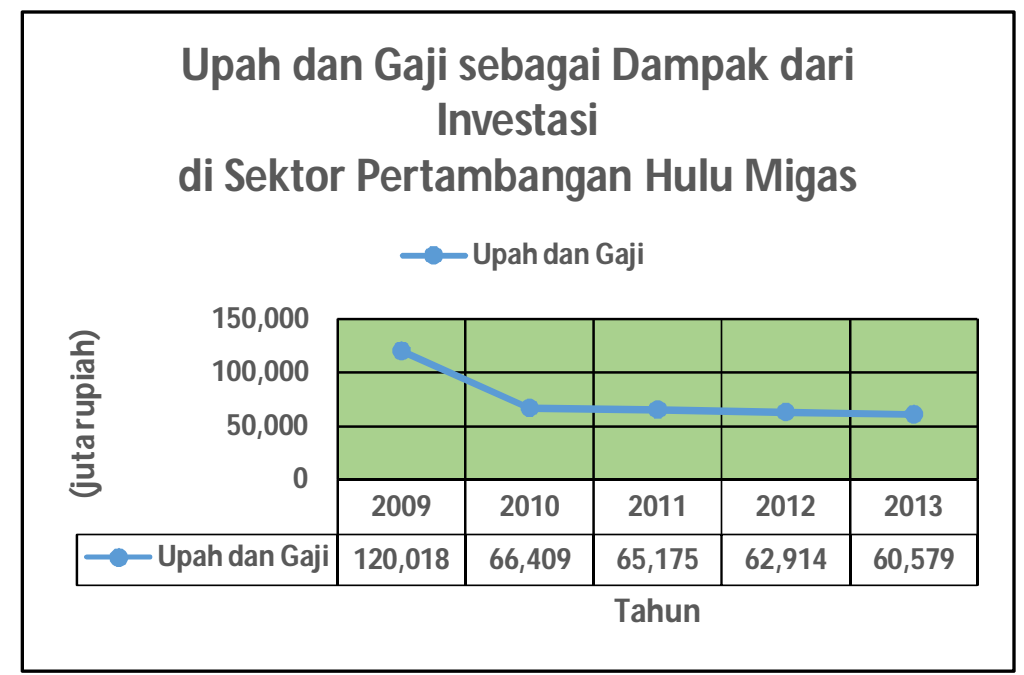

Gambar 4. Dampak Investasi di Sektor Pertambangan Hulu Migas terhadap Upah dan Gaji

Searah dengan penurunan investasi dan penurunan nilai tambah bruto di sektor pertambangan hulu migas, penyusutan dari sektor ini juga terus menurun selama periode 2009-2013, dari Rp. 49.757 juta di tahun 2009 menjadi Rp. 25.115 juta di tahun 2013. Rata-rata penyusutan di sektor pertambangan hulu migas selama periode 2009-2013 adalah sebesar Rp. 31.102 juta. Penyusutan rata-rata pertahun selama periode 2009-2013 yang diperoleh dari investasi di sektor pertambangan hulu migas adalah sebesar 3,5 persen dari investasi. 


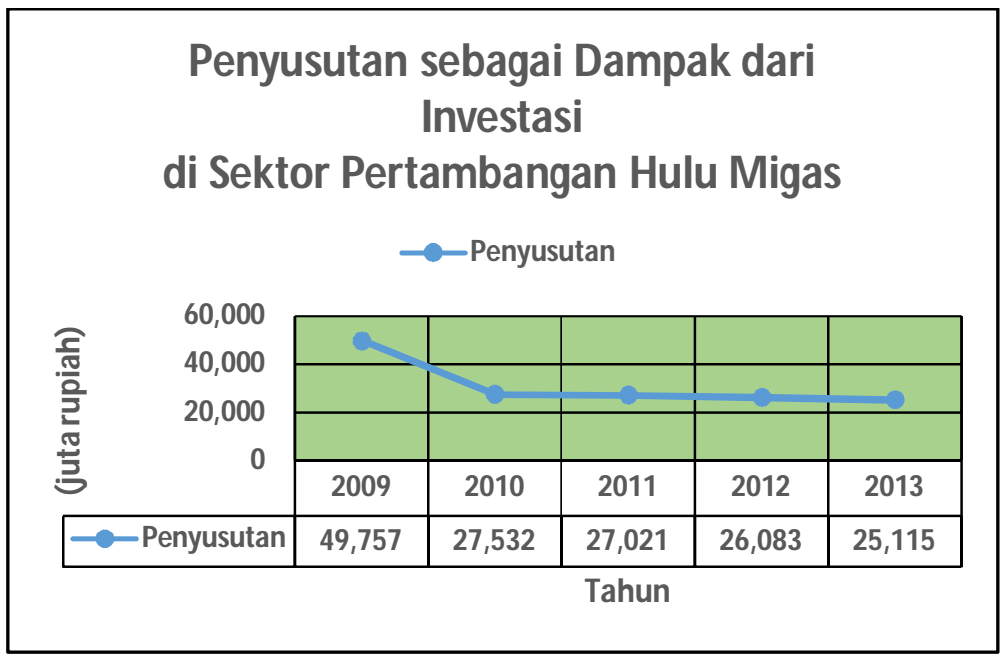

Gambar 5. Dampak Investasi di Sektor Pertambangan Hulu Migas terhadap Penyusutan

Searah dengan penurunan investasi dan penurunan nilai tambah bruto di sektor pertambangan hulu migas, pajak tak langsung dari sektor ini juga terus menurun selama periode 2009-2013, dari Rp.62.921 juta di tahun 2009 menjadi Rp.31.759 juta di tahun 2013. Rata-rata pajak tak langsung di sektor pertambangan hulu migas selama periode 2009-2013 sebesar Rp.39.330 juta. Pajak tak langsung rata-rata pertahun yang diperoleh dari investasi di sektor pertambangan hulu migas adalah sebesar 4,4 persen dari investasi.

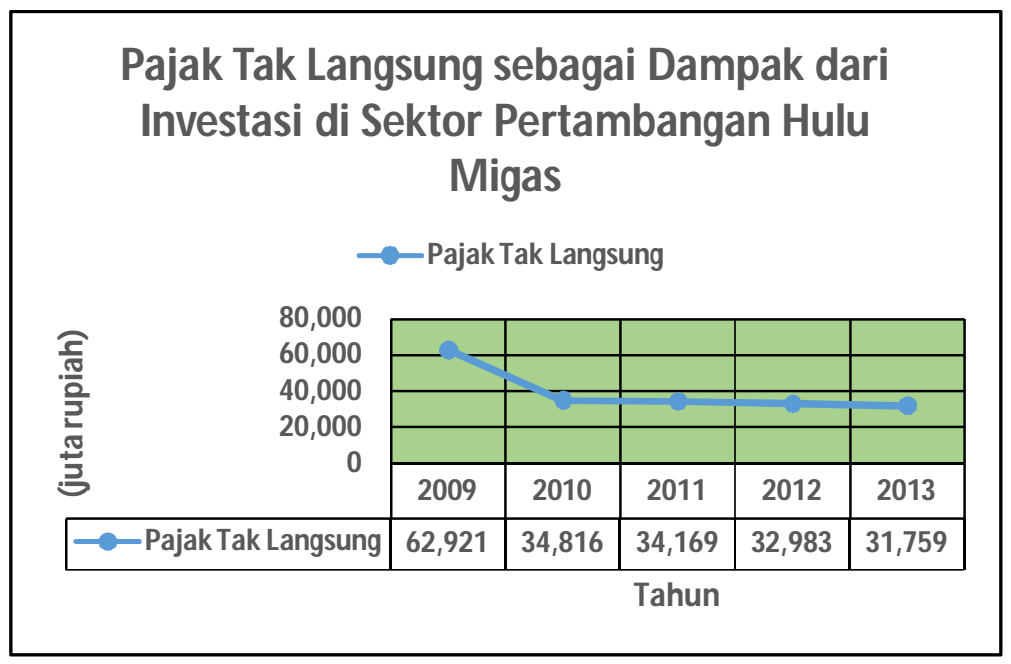

Gambar .6. Dampak Investasi di Sektor Pertambangan Hulu Migas terhadap Pajak Tak Langsung

Jika dibandingkan dampak investasi terhadap komponen-komponen nilai tambah bruto, tampak bahwa dampak investasi terhadap surplus usaha $(81,2 \%)$ lebih besar daripada dampak investasi terhadap gaji dan upah $(8,4 \%)$, penyusutan $(3,5 \%)$, dan pajak tak langsung $(4,4 \%)$. Searah dengan penurunan investasi di sektor pertambangan hulu migas, penyerapan tenaga kerja dari sektor ini juga terus menurun selama periode 2009-2013, dari 2.107 orang di tahun 2009 menjadi 1.063 orang di tahun 2013. Rata-rata penyerapan tenaga kerja di sektor pertambangan hulu migas selama periode 2009-2013 adalah sebesar 1.317 orang. Penyerapan tenaga kerja rata-rata pertahun yang 
diperoleh dari investasi adalah sebesar 0,0015 orang per satu juta rupiah investasi atau sekitar 2 orang per satu miliar rupiah investasi.

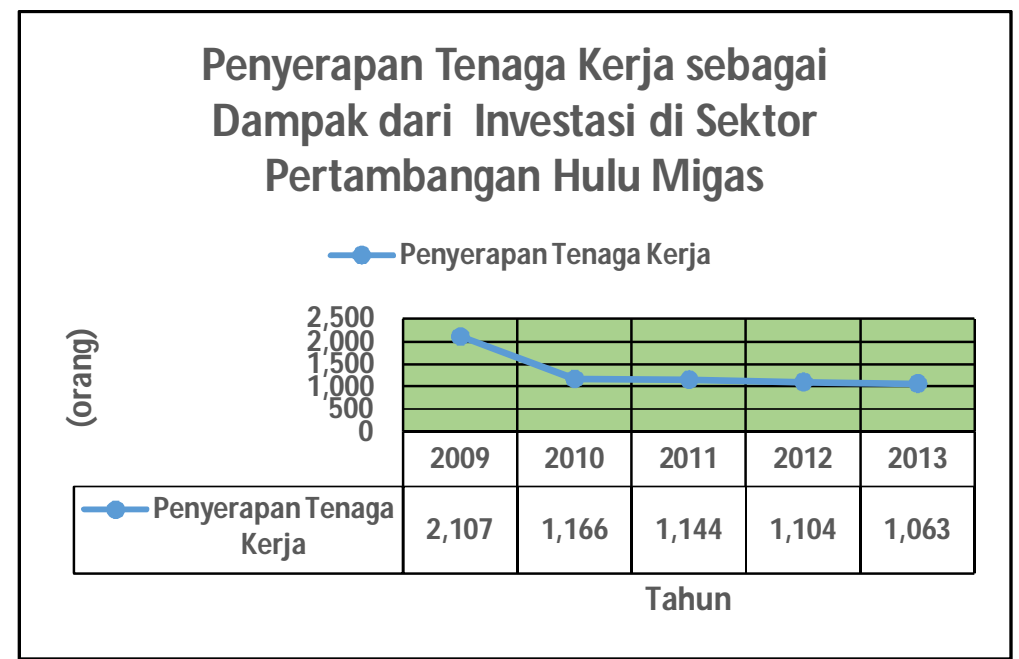

Gambar 7. Dampak Investasi di Sektor Pertambangan Hulu Migas terhadap Penyerapan Tenaga Kerja

Masih rendahnya dampak investasi terhadap penyerapan tenaga kerja selain menunjukkan bahwa sektor pertambangan hulu migas cenderung capital/technology intensive dari pada labour intensive juga menunjukkan bahwa sektor ini lebih banyak menyerap tenaga kerja asing dari pada tenaga kerja domestik. Searah dengan penurunan investasi di sektor pertambangan hulu migas, import content dari sektor ini juga terus menurun selama periode 2009-2013, dari Rp. 30.993 juta di tahun 2009 menjadi Rp. 15.644 juta di tahun 2013. Rata-rata import content di sektor pertambangan hulu migas selama periode 2009-2013 adalah sebesar Rp. 19.373 juta. Import content rata-rata pertahun yang diperoleh dari investasi adalah sebesar 2,2 persen dari investasi.

\section{KESIMPULAN}

Dampak investasi sector pertambangan hulu migas terhadap nilai tambah bruto (surplus usaha, upah, penyusutan, dan pajak tak langsung), penyerapan tenaga kerja, dan impor. Data penelitian dikumpulkan melalui berbagai sumber eksternal dan disintesa dengan análisis kritis untuk menjelaskan keterkaitan investasi sector pertambangan Indonesia. Secara umum, hasil penelitian menunjukkan bahwa investasi sektor pertambangan hulu migas berdampak positif terhadap nilai tambah bruto beserta komponennya (surplus usaha, upah dan gaji, penyusutan, pajak tak langsung), penyerapan tenaga kerja, dan import content. Secara khusus, berdasarkan perumusan masalah, tujuan penelitian, dan hasil penelitian, dapat diambil kesimpulan sebagai berikut:

Investasi sektor pertambangan hulu migas berdampak positif terhadap nilai tambah bruto beserta komponennya yang terbagi ke dalam surplus usaha, upah dan gaji, penyusutan, dan pajak tak langsung. Menurunnya investasi sektor pertambangan hulu migas berdampak pada menurunnya nilai tambah bruto beserta komponennya. Nilai tambah bruto rata-rata pertahun selama periode 2009-2013 yang diperoleh dari investasi di sektor pertambangan hulu migas adalah sebesar $97,6 \%$ dari investasi. Dampak investasi sektor pertambangan hulu migas terhadap surplus usaha $(81,2 \%)$ lebih besar daripada dampak investasi terhadap gaji dan upah $(8,4 \%)$, penyusutan $(3,5 \%)$, dan pajak tak langsung $(4,4 \%)$.

Investasi pertambangan sektor hulu migas berdampak positif terhadap penyerapan tenaga kerja. Menurunnya investasi sektor pertambangan hulu migas berdampak pada menurunnya penyerapan tenaga kerja. Penyerapan tenaga kerja rata-rata pertahun yang diperoleh dari investasi 
di sektor pertambangan hulu migas adalah sebesar 0,0015 orang per satu juta rupiah investasi atau sekitar 2 orang per satu miliar rupiah investasi. Masih rendahnya dampak investasi terhadap penyerapan tenaga kerja menunjukkan bahwa sektor pertambangan hulu migas cenderung capital/technology intensive daripada labour intensive.

Investasi pertambangan sektor hulu migas berdampak positif terhadap import content. Menurunnya investasi sektor pertambangan hulu migas berdampak pada menurunnya import content. Import content rata-rata pertahun selama periode 2009-2013 yang diperoleh dari investasi di sektor pertambangan hulu migas adalah sebesar 2,2 persen dari investasi.

Implikasi

Sebagai implikasi dari penelitian ini disarankan bagi penelitian selanjutnya untuk meneliti tentang faktor-faktor yang mempengaruhi investasi di sektor pertambangan hulu migas serta dampak investasi sektor hilir migas terhadap nilai tambah bruto, penyerapan tenaga kerja dan import content. Penelitian lanjutan ini diperlukan agar dapat dibandingkan peran sektor hulu migas dan hilir migas dalam pembangunan.

Penelitian ini menyarankan kepada pemerintah untuk secara berkelanjutan menetapkan dan mengevaluasi kebijakan investasi dalam menciptakan iklim investasi yang sehat yang mampu mendorong makin meningkatnya investasi di sektor hulu migas, termasuk secara konsisten memberantas mafia migas. Kebijakan pemerintah untuk memperbaiki peringkat kemudahan berbisnis di Indonesia melalui paket kebijakan ekonomi jilid XII disarankan untuk terus di awasi pelaksanaannya dan ditingkatkan efektivitasnya agar kemudahan dalam berbisnis dan perlindungan investor yang dijanjikan dapat direalisasikan. Disarankan pula untuk terus memperbesar TKDN dalam pengadaan barang dan jasa di sektor pertambangan hulu migas dan mensinergikannya dengan peningkatan penyerapan tenaga kerja domestik di sektor pertambangan hulu migas.

\section{REFERENSI}

Apergis N, Payne JE. Renewable and non-renewable energy consumption-growth nexus: evidence from a panel error correction model. Energy Econ 2012;34(3):733e8.

Bank Indonesia (2015). Produk Domestik Bruto (PDB). Departemen Statistik Ekonomi dan Moneter, Bank Indonesia.

Kaygusuz K. Energy for sustainable development: key issues and challenges. Energy Sources B Energy Econ Plann 2007;2(1):73 83.

Kementerian ESDM (2015). Handbook. Jakarta: Kementerian ESDM

Kaygusuz K. Energy for sustainable development: key issues and challenges. Energy Sources B Energy Econ Plann 2007;2(1):73 83.

Si, S., Lyu, M., Lawell, C. Y. C. L., \& Chen, S. (2018). The effects of energy-related policies on energy consumption in China. Energy Economics, 76, 202-227.

Wang, S., Li, G., \& Fang, C. (2018). Urbanization, economic growth, energy consumption, and CO2 emissions: Empirical evidence from countries with different income levels. Renewable and Sustainable Energy Reviews, 81, 2144-2159. 
Jurnal Manajemen Strategi dan Aplikasi Bisnis, 2(2), 137-144

Effendy, N. Analisa dampak investasi...

\section{PROFIL PENULIS}

Dr. Nazorry Effendy merupakan dosen di prodi Manajemen, STIE Pengembangan Bisnis \& Manajemen, Jakarta, Indonesia. 